\title{
ANALYSIS OF ELECTRIC BICYCLES AS A VEHICLE IN INDONESIA: A NORMATIVE LEGAL REVIEW
}

\author{
Febrina Gladys Elvira \\ Fakultas Hukum Universitas Airlangga \\ J1. Dharmawangsa Dalam Selatan, Airlangga, Surabaya \\ e-mail: febrina.gladys.elvira@gmail.com \\ Sri Sukmana Damayanti \\ Fakultas Hukum Universitas Airlangga \\ Jl. Dharmawangsa Dalam Selatan, Airlangga, Surabaya \\ e-mail: Srisukmanad@gmail.com \\ Gavrilla Theodora \\ Fakultas Hukum Universitas Airlangga \\ Jl. Dharmawangsa Dalam Selatan, Airlangga, Surabaya \\ e-mail:gevi.theodora@gmail.com \\ Olga Nadina \\ Fakultas Hukum Universitas Airlangga \\ Jl. Dharmawangsa Dalam Selatan, Airlangga, Surabaya \\ e-mail: olganadin.on@gmail.com
}

\begin{abstract}
Abstrak: Dalam perkembangannya terdapat kendaraan berupa sepeda listrik yang notabene memiliki dua sumber energi yaitu energi manusia dan energi listrik. Kendaraan yang memiliki dua sumber energi penggerak ini disebut juga sebagai bybrid vehicle. Di dalam peraturan perundang-undangan di Indonesia terkait dengan hybrid vehicle, yang notabene memiliki dua sumber energi, seperti sepeda listrik yang menggabungkan energi manusia dan listrik tidak terdapat pengaturan. Hal ini menimbulkan problematika terkait dengan legalitas sepeda listrik yang ada di masyarakat. Ketidakjelasan legalitas sepeda listrik ini memiliki problematik hukum yaitu 1) kedudukan hukum sepeda listrik di Indonesia dan 2) akibat hukum sepeda listrik sebagai kendaraan di Indonesia. Penelitian ini adalah penelitian hukum normatif dengan menggunakan pendekatan peraturan perundang-undangan (statute approach) dan pendekatan konseptual (conceptual approach). Berdasarkan penelitian ini, ditemukan bahwa sepeda listrik tergolong sebagai kendaraan tidak bermotor. Hal ini didasarkan pada argumentasi bahwa sumber utama tenaga penggerak sepeda listrik adalah tenaga manusia dan dengan penafsiran ekstensif sepeda listrik merupakan perluasan dari sepeda pada umumnya. Akibat hukum yang muncul ketika sepeda listrik tergolong sebagai kendaraan tidak bermotor, berarti terdapat hak dan kewajiban hukum bagi pengendara sepeda listrik tersebut. Terdapat dua klasifikasi kewajiban bagi pengemudi sepeda listrik, dimana terdapat kewajiban yang hanya bersifat anjuran karena tidak memiliki sanksi ketika tidak dilaksanakan dan kewajiban yang memiliki sanksi ketika tidak dilaksanakan. Adapun hak-hak bagi pengemudi sepeda listrik adalah terdapat fasilitas-fasilitas khusus bagi pengendara sepeda listrik
\end{abstract}

Kata Kunci: sepeda listrik, legalitas, kendaraan. 


\begin{abstract}
In its development, there is a vehicle in the form of electric bicycles which incidentally has two sources of energy namely human energy and electrical energy. This vehicle that has two sources of propulsion energy is also called hybrid vehicles. Though, there is not yet an Indonesian regulations related to hybrid vehicles, which has two energy sources, such as electric bicycles that combine human energy and electricity. This raises problems related to the legality of electric bicycles in the society. The unclear legality of electric bicycles has legal problems namely 1) the legal standing of electric bicycles in Indonesia and 2) legal consequences of electric bicycles as vehicles in Indonesia. This research is a normative legal research with a statutory and conceptual approach. Based on this research, it was found that electric bicycles are classified as non-motorized vehicles. This is based on the argument that the main source of electric bicycle driving force is human power and with an extensive interpretation of electric bikes as an extended version of a bicycle in general. The legal consequences that arise when electric bicycles are classified as non-motorized vehicles are the legal rights and obligations for the electric cyclist. There are two classifications of liabilities for electric bicycle riders, where there are obligations that are in the form of cautionary suggestions because they do not have sanctions or punishment for not implementing the recommendation and ones that have sanctions when not applied. One of the rights received by electric bicycle drivers are special facilities for electric bicycle riders
\end{abstract}

Keywords: electric bicycle, legality, vehicle.

\section{INTRODUCTION}

Technology mutantur semper, a Latin expression that translates into technology, will always change. The sentence is an appropriate expression to reflect the development of technology, which develops at a magnificent speed fast, especially after the world entered the era of the industrial revolution since 1784 , where the steam engine was invented. ${ }^{1}$ Since then, various technologies have been born in human life, such as cars, motorcycles, computers, the internet, artificial intelligence, and so on.
One of the new technologies that are currently starting to circulate in Indonesia is an electric bicycle. This electric bicycle is an innovation in the world of transportation. In general, there are indeed some similarities between electric bicycles and bicycles, such as physically, the shape of an electric bicycle is not much different from ordinary bicycles, this electric bicycle, also still uses pedals and human power as the main driving force, but there are still differences in between the two. The differences between electric bicycles and bicycles in general include: ${ }^{2}$ :
${ }^{1}$ Haradhan Mohajan, "The First Industrial Revolution: Creation of a New Global Human Era," Journal of Social Sciences and Humanities 5, no. 4 (2019): 377-87.
${ }^{2}$ Rachel Berney, Bicycle Urbanism: Reimagining Bicycle Friendly Cities (New York: Routledge, 2018). 
1. Electric bikes include rechargeable batteries with 250-1000-watt power and an electric motor.

2. The electric battery and electric motor can be used as auxiliary power in pedaling (interchangeable electric pedal-assist) and / or as a prime driving power (throttle) for a certain amount of time.

3. The average speed of electric bicycles is $25 \mathrm{~km} /$ hour, and for some types can reach a top speed of $80 \mathrm{~km} /$ hour.

Based on these differences, it can be seen that the main difference between electric bicycles and bicycles in general, namely electric bikes, combines electrical energy and human energy as driving power. By combining electric energy and human, the aim is for bicycle drivers to have a choice of riding the bicycle, which can use human energy or use electric power purely (though only temporarily). This feature will undoubtedly be very beneficial for the rider. The combination of engine and human energy as a driving force in electric bicycles makes this vehicle also called a hybrid vehicle. $^{3}$

The magnificently fast development of technology has created an electric bicycle, which incidentally was a hybrid vehicle, apparently unable to be followed by law.
The inability of the law to support this development has been contained in the adage of classical law, namely het recht bink anter de feiten, that the law will always be left behind, ${ }^{4}$ including being left behind with technology. The legal setback with this technology can be seen from the absence of precise legal arrangements related to electric bicycles in Indonesia, even though electric bicycles have been circulating for some time nowadays.

In Indonesia, the legal position of this electric bicycle does not yet have a clear position. If we look at the laws and regulations in Indonesia, vehicles are classified into three, namely:

a) Motorized vehicles

In Article 1, number 8 of Law No. 22 of 2009 concerning Road Traffic and Transport (Law 22/2009) jo. Article 1 number 2 Government Regulation No. 55 of 2012 concerning Vehicles (PP 55/2012), regulates that motorized vehicles are every vehicle that is driven by mechanical equipment in the form of machinery other than vehicles that run on the train tracks

b) Battery-based electric motorized vehicles

In Article 1 number 3 of Presidential Regulation No. 55 of 2019 (PP
3 Antonio García Javier et al., "Performance And Emissions Of A Series Hybrid Vehicle Powered By A Gasoline Partially Premixed Combustion Engine," Applied Thermal Engineering 150, no. 5 (2019): 564-75.

\footnotetext{
4 Eddy Omar Sharif Hiariej, "United Nations Convention Against Corruption Dalam Sistem Hukum Indonesia," Mimbar Hukum - Fakultas Hukum Universitas Gadjab Mada 31, no. 1 (2019): 112, doi:10.22146/jmh.43968.
} 
55/2019) concerning the Acceleration of Battery-Based Electric Vehicle for Road Transportation Program, stipulated that battery-based vehicle are vehicles that are driven by electric motors and obtain a direct supply of electric power from batteries in a vehicle or from outside

c) Non-motorized vehicles

In Article 1 number 9 of Law 22/2009 jo. Article 1 number 3 PP 55/2012, stipulated that non-motorized vehicles are every vehicle that is driven by human and / or animal labor.

Based on the three-vehicle classifications, it can be seen that this electric bicycle has an unclear legal status between being classified as a battery-based vehicle, non-motorized vehicles, or even neither. This, because if it wants to be classified as a battery-based vehicle, then it is not entirely complied with the specification because an electric bicycle can also be driven by human power. On the other hand, if it is classified in nonmotorized vehicles, electric bicycles can also use batteries as the primary source to drive these electric bicycles.

The existence of the unclear legal status of electric bicycles in the laws and regulations in Indonesia, causing problems related to the legality of electric bikes in Indonesia. As some time ago, a dispute between Polda Metro Jaya and Migo (Migo Holdings Limited), an application-based electric bicycle rental company (e-bike sharing), happened.

From the Metro Jaya Regional Police opinion, the electric bicycle rented by Migo cannot be classified as a non-motorized vehicle in the form of a bicycle. Furthermore, the Jakarta Police will search for Migo electric bicycles that operate on the highway. Migo believes that the electric bicycles they rent out can still be classified as non-motorized vehicles in the form of bicycles because although Migo electric bicycles use some electrical components, there are still pedals for pedaling. ${ }^{5}$

This ambiguity associated with the legality of this electric bicycle certainly has juridical consequences. One of the juridical consequences is related to the implications of the legal consequences of this electric bicycle. The legal consequences in question are related to rights and obligations for electric bicycle and electric bicycle drivers/riders themselves. There are unclear rights and obligations for electric bicycle and electric bicycle drivers, which still unclear to be classified as battery-based vehicles or non-motorized vehicles.
5 Bingah Amarwata Sujana, "Kedudukan Sepeda Listrik Dalam Hukum Positif Di Indonesia," Hukumonline, 2020 , https://www.hukumonline.com/berita/baca/lt5e7 1b6f6af9dc/kedudukan-sepeda-listrik-dalamhukum-positif-di-indonesia-oleh--bingahamarwata-sujana/. 
The existence of ambiguity related to the legality of electric bicycles was born due to the inability of the law to keep up with technological developments, especially as Indonesia, which is a civil law system where the main source of law is legislation, which is certainly very dependent on lawmakers to provide the law. ${ }^{6}$ In the absence of regulations related to electric bicycles, this does not mean that these electric bicycles must be negated, instead there is a need for studies that can co-correlate between law and technology (electric bikes). This is according to Rachel Buchananhe's opinion, which is: ${ }^{7}$

"The relationship between law and technology forms is two distinct areas for discussion and debate, but both are intertwined and no discussion is complete without acknowledging the other." Based on this background, the formulations of the problem in this study are:

1. Legal status of electric bicycles in Indonesia

2. The legal consequences of electric bicycles as vehicles in Indonesia

\section{METHOD}

This research is a normative or doctrinal legal research that is carried out by method under the unique character of jurisprudence and is different from social science or natural science. ${ }^{8}$ Doctrinal research is research that provides a systematic explanation of the provisions governing certain areas of law, analyzes the relationship between these provisions, explains the problem, and perhaps, predicts its development. ${ }^{9}$

According to Peter Mahmud Marzuki, "legal research is a process to find the rule of law, legal principles, and legal doctrines to address the legal issues in question", ${ }^{10}$ especially those regarding the Legality of Electric Bicycles as Vehicle in Indonesia. Still, according to Peter Mahmud, "legal research is carried out to produce new arguments, theories or concepts as a prescription in solving the problem." 11

The approach used in normative legal research is the statute approach and conceptual approach. Statute approach is applied to examine various laws and regulations related to the legal matter in question, including Law 22/2009, PP (Government Regulation) 55/2012, PP
6 Muksana Pasaribu, "Kedudukan Hukum Islam Dalam Sistem Civil Law Dan Sistem Common Law," Jurnal Justitia 7, no. 1 (2020).

7 Rachel Buchanan, "The Role Of Technology In The Future Of Legal Professions," University of Oxford, 2017, https://www.law.ox.ac.uk/researchand-subject-groups/research-collection-law-andtechnology/blog/2017/02/role-technology.

\footnotetext{
${ }^{8}$ Depri Liber Sonata, "Metode Penelitian Hukum Normatif Dan Empiris: Karakteristik Khas Dari Metode Meneliti Hukum," Fiat Justitia Jurnal Ilmu Hukum 8, no. 1 (2017): 25.

9 Terry Hutchinson, Researching and Writing in Law (Sydney: Lawbook Co, 2002).

10 Peter Mahmud Marzuki, Penelitian Hukum (Jakarta: Prenada Media Group, 2010).

${ }^{11}$ Ibid.
} 
55/2019, and so on. "This statutory approach will open up opportunities for researchers to learn whether there are consistency and the red line between one law and another or between laws with the constitution or between regulations and laws". ${ }^{12}$

The conceptual approach, according to Peter Mahmud Marzuki, is conducted to study the views and doctrines in legal science as well as to find legal understandings, legal concepts, and legal principles relevant to the issue. ${ }^{13}$ The legal concepts used are concepts relating to the legality of electric bicycles as vehicles in Indonesia.

\section{RESULTS AND DISCUSSION}

\section{Legal Status of Electric Bicycles in}

\section{Indonesia}

Ex falso quo libet, misunderstanding of a concept may result in drawing wrong conclusions. The legal adage is a sign that in not to misunderstand a legal concept as it will lead to a false understanding as well. ${ }^{14}$

In connection with understanding the legal standing of electric bikes in Indonesia, it must be understood in advance related to the concept of the vehicle itself. As explained earlier, there are three types of

\section{Ibid.}

13 Ibid.

14 Xavier Nugraha and Ave Maria Frisa Katherina,

"Tanggung Jawab Promotor Perseroan Terbatas vehicles in Indonesian laws and regulations, namely:

1. Motorized vehicles

2. Battery based vehicles

3. Non-motorized vehicles

As described above, based on Article 1 number 8 of Law 22/2009 jo. Article 1 number 2 PP 55/2012 motorized vehicles are every vehicle that is driven by mechanical equipment in the form of machines other than vehicles that run on train tracks. Based on Article 47 paragraph (2) of Law 22/2009 and Article 3 paragraph (1) PP 55/2012, motor vehicles consist of motorbikes, passenger cars, bus cars, freight cars, and special vehicles. This special vehicle, based on Article 5 paragraph (6) PP $55 / 2012$ is a vehicle that has a military function, public order and security, production equipment, and mobility of people with disabilities.

As described above, based on Article 1 number 9 of Law 22/2009 jo. Article 1 number 3 PP 55/2012 non-motorized vehicles are every vehicle that is driven by human and / or animal labor. Based on Article 47 paragraph (4) of Law no. 22/2009 and Article 4 PP 55/2012, nonmotorized vehicles are only grouped into two, namely vehicles are driven by human power and vehicles driven by animal power.

Terhadap Kontrak Pra Inkorporasi Di Indonesia," Media Iuris 2, no. 127-155 (2019). 
In Article 114 PP 55/2012, nonmotorized vehicles that are driven by manpower consist of bicycles, rickshaws, and wheelbarrows. Non-motorized vehicles pulled by animal power consist of trains, horse carts, and cikar (cart pulled by cows or buffaloes).

Based on Article 1 number 3 Perpres $55 / 2019$ battery-based vehicles is a vehicle that is driven by an electric motor and gets an electric power supply from the battery directly in the vehicle or from outside. In Article 2 paragraph (1) of Presidential Regulation 55/2019, battery-based vehicles are classified into two, namely, one that based on two-wheels and / or tricycle and one that based on four-wheels or more.

If you look at the three classifications of these vehicles, it can be said that electric bikes, which are hybrid vehicles that combine electrical and human energy, cannot be classified in the three-vehicle classifications. The arguments underlying this opinion are:

\section{Grammatical Interpretation}

Grammatical interpretation is the interpretation used to find out the meaning of the provisions of the Act by describing it according to common everyday language. ${ }^{15}$ Thus, the grammatical interpretation seen first is the sound of a rule as it is according to grammatical structure. ${ }^{16}$ If we see it grammatically, in the regulations of battery-based vehicles, and nonmotorized vehicles, it can be seen that each of the vehicle classifications has imitatively regulated the driving force of the vehicle classification. All vehicles that use fuel-engine as a driving source must be classified as motorized vehicles, all vehicles that use electric-battery motors as a driving source must be classified as batterybased, and All vehicles that use human (or animal) power as a driving source, must be classified as a non-motorized vehicle. There is no classification of vehicles that use two driving force sources.

2. Interpretation of Originalism

Scire leges non hoc est verba earum tenere, sed vim ac potestatem, ${ }^{17}$ although the law is written, it must be interpreted under the legislator. A legal adage that has meaning, that to understand holistically a statutory regulation must be examined by the legislators themselves. This is the basis of the interpretation of originalism, which
15 Sryani Br. Ginting, "Interpretasi Gramatikal Sistematis Historis Kasus Dugaan Penodaan Agama Oleh Ahok," Law Pro Justitia 2, no. 2 (2017): 61-75. 16 Sitti Mawar, "Metode Penemuan Hukum (Interpretasi Dan Konstruksi) Dalam Rangka Harmonisasi Hukum," Jurnal Justitia 1, no. 1 (2016): $1-18$.
17 Зезюля А.М., "ВклаА В Имущество И ВклаА В Уставный Капитал: Соотношение Понятий,” in Российская Наука в Современном Мире» ХХVIII Международная Научно-Практическая Конферениия (Moscow: Research and Publishing Center, 2020), 212-13. 
means the rule is under the wishes of the rule maker, which in the context of the Law can be seen in academic text. ${ }^{18}$ In the academic text of Law 22/2009, we will not find any discussion related to electric bicycles. This shows that when the legislators made Law no. 22/2009, the legislators did not think that there would be an electric bicycle that would be a hybrid vehicle, which was a vehicle that combined electrical and human energy.

When Law no. 22/2009, which is a lex generalis of the rules relating to vehicles, then automatically the rules preceded after will not regulate the same thing. Thus, initially, electric bicycles cannot be said to belong to any vehicle classification in the existing legislation

If you look at these arrangements rigidly and textually, then surely this electric bicycle is not classified in any vehicle classification. This shows that there is no regulation related to electric bicycles, although sociologically these electric bicycles are in the community and there are a lot of them found.

When the interpretation is used in absolute, then this will cause a recbtvacuum (legal vacuum) that should not occur in a state of law, which incidentally uses the law as the supreme commander. ${ }^{19}$

To prevent the legal vacuum associated with the regulation of electric bicycles, law enforcers should interpret the existence of electric bikes progressively under Satjipto Rahardjo's progressive legal theory. Satjipto Rahardjo's progressive legal theory places laws for humans, not humans for laws which means the behavior is far more important as a significant factor in law than regulations which are nothing but texts. ${ }^{20}$

According to Satjipto Rahardjo, the legal texts cannot be fully trusted as an authentic representation of legal life. ${ }^{21}$ When the interpretation of the law is only interpreted under legal texts which incidentally changes very slowly, then the law will not produce substantive "defiance of norms", but only procedural. ${ }^{22}$

Based on a progressive legal approach to understanding the legal position of these electric bicycles, the classification of the most appropriate vehicles for electric bicycles is non-motorized vehicles. The arguments underlying these opinions are:

1. The Main Source of Driving Power of Electric Bicycles is Human Power

\footnotetext{
18 Suanro, "Kewenangan Komisi Yudisial Dalam Tafsir Mahkamah Konstitusi:Kajian Putusan Mahkamah Konstitusi Nomor 43/Puu-Xiii/2015," Jurnal Yudisial 9, no. 2 (2016): 131-50.

19 Muwahid, "Metode Penemuan Hukum (Rechtsvinding) Oleh Hakim Dalam Upaya

Mewujudkan Hukum Yang Responsif," Al-Hukama 7, no. 1 (2017): 225-48.

${ }^{20}$ Ibid.

${ }^{21}$ Ibid.

22 Hyronimus Rhiti, "Landasan Filosofi Hukum Progresif," Justitia Et Pax 32, no. 1 (2016): 34-48.
} 
If you understand textually in the legislation related to the classification of vehicles, it is indeed divided into "sources of driving force", but if we understand them contextually, we will realize, that the classification is based on the main source of driving force.

Electric bicycles are indeed hybrid vehicles that incidentally have two sources of the driving force, namely electric power and human power, but if you look at the main source of power from electric bicycles is human power. Indeed, electric power can be used as the main source of propulsion from electric bicycles, but it is only temporary. When the energy source runs out, the main source of propulsion from the electric bicycle is human power.

2. Based on Extensive Interpretation of Electric Bicycles is an Expansion of Bicycles in General

Extensive interpretation is a method of interpretation

which makes interpretations exceed the limits of the results of grammatical interpretation. ${ }^{23}$ This interpretation tries to expand the meaning that is in the legislation, therefore it is not only interpreted narrowly but broadly.
Extensively, we can see that the definition of a Non-Motorized Vehicle is "every Vehicle that is driven by human and/or animal power." This means, extensively, the phrase "every vehicle" can be interpreted as any vehicle that uses human and / or animal power, which means broadly electric bicycles that also use human power including non-motorized vehicles, that in some occasion the power source is electricity

This is an extension of the meaning of every vehicle that uses human power, which is not limited to only vehicles whose energy source is human power, but also vehicles whose energy sources are human power and electric power.

\section{The Legal Impact of Electric Bicycles as a Vehicle in Indonesia}

Based on the above analysis, it can be seen that the position of electric bicycles in Indonesia is classified as non-motorized vehicles. When electric bicycles are classified as non-motorized vehicles, then, of course, there will be legal consequences of the classification of electric bikes as nonmotorized vehicles which in fact will be different when electric bicycles are batterybased or motorized vehicles. The legal
23 Agus Priono, Widodo T. Novianto, and I Gusti Ayu Ketut Rachmi Handayani, "Penerapan Teori Penafsiran Hukum Oleh Hakim Sebagai Upaya Perlindungan Hukum Terhadap Notaris (Studi Atas
Putusan Hakim Terhadap Tindak Pidana Pemalsuan Akta Otentik)," Jurnal Pasca Sarjana Hukum UNS 5, no. 2 (2017): 117-30. 
consequences referred to are related to the rights and obligations that arise.

In connection with legal obligations, theoretically, the norm of this obligation is divided into two, namely the command norm (gebod) and the prohibition norm (verbod). ${ }^{24}$ Command norms are norms that contain the community's obligation to do something that is obliged. ${ }^{25}$ Norms operator of orders and prohibition, for example, are mandatory, prohibited, and so on. ${ }^{26}$ Under this norm of obligation, when not implemented, there are legal sanctions that will be accepted by the subject of the norm. 27

In-Law 22/2009, apparently not all legal obligations contained therein have legal sanctions. This has led to two classifications related to legal obligation norms in Law 22/2009, namely:

1. Norms of Obligation Regarding Suggestions Due to Not Include Sanctions If the Provisions are Not Obeyed.

2. Norms of Liability That Are Punished with Sanctions If Not Complied With

Norms of liability that is not included in sanctions if these provisions are not adhered to and usually considered to be mere suggestions. This is because there are no sanctions or juridical consequences when the obligation norms are not followed. Norms of obligation that are not followed by this sanction, can be said to be imperfect norms because even though the "spirit" is a norm of obligation, there are no sanctions when not followed. Theoretically, the imperfect liability norm is referred to as lex imperfecta. ${ }^{28}$

Some provisions relating to legal obligations for electric bicycles that are only recommendations/suggestions include:

1. In Article 61 paragraph (1) of Law $22 / 2009$, it is regulated with obligations for electric bicycle riders, that every Non-Motorized Vehicle operated on the road must meet the safety requirements including:

a) Technical Requirements

In Article 61 paragraph (2) of Law $22 / 2009$, it is regulated that what is meant by technical requirements include:

1. construction;

2. steering system;

3. wheel system;

4. brake system;

5. lights and reflectors; and
24 Wagiman, "Nilai, Asas, Norma, Dan Fakta Hukum: Upaya Menjelaskan Dan Menjernihkan Pemahamannya," Filsafat Hukum 1, no. 1 (2016): 43-73.

25 Ibid.

26 Wagiman, "Nilai, Asas, Norma, Dan Fakta Hukum: Upaya Menjelaskan Dan Menjernihkan Pemahamannya."

\footnotetext{
27 Eko Supriyanto, "Kedudukan Naskah Akademik Dalam Penafsiran Ketentuan-Ketentuan Dalam Undang-Undang," Yuridika 31, no. 3 (2016): 384 400.

28 Thomas A.J. Mcginn, "The Expressive Function of Law and the Lex Imperfecta," Roman Legal Tradition 11, no. 1 (2015): 1-41.
} 
6. warning equipment with a sound.

This means, when an electric bicycle will be operated, these six things are important things that must be fulfilled before it is operated

b) Requirements for Procedure for Loading Goods

In Article 61 paragraph (3), the requirements for procedures for loading goods is related to volume and dimensions. This means that the size of the electric bicycle must be considered for its volume and dimensions, which should not attract and disturb other road users.

2. Article 122 paragraph (2) of Law $22 / 2009$ stipulated that 2) cyclists are prohibited from carrying passengers unless the bicycle has been equipped with a passenger seat. If you look at the current electric bicycle, it can be seen that there are no seats for passengers, so that it can be interpreted, that it is not allowed to carry passengers on electric bicycles.

3. In Article 123 of Law 22/2009, it is determined that deaf cyclists must use identification cards that are placed on the front and back of their bicycles. This certainly applies to electric bicycle drivers, so it must also be given an ID.

4. In Article 115 paragraph (2) letter a of Government Regulation (PP) 55/2012 it is regulated that bicycles must have fenders. In Article 114 paragraph (3) PP $55 / 2012$ it is regulated that the fender is attached to reduce water splashing backward, and has a width of at least the same as the sole of the tire. This means electric bicycles must have fenders under Article 3 of PP (Government Regulation) 55/2012

5. In Article 115 paragraph (2) letter b of PP (Government Regulation) no. $55 / 2012$ it is regulated that bicycles must have brakes. In Article 115 paragraph (4) and paragraph (5) PP $55 / 2012$, it is regulated that the brakes must function properly to slow down and stop the bicycle, and at least be mounted on the cogs according to the size of the load. This means that electric bicycles must have brakes and the brakes must be under the provisions in Article 115 paragraph (4) and paragraph (5) PP 55/2012

Some of these provisions are mandatory provisions for electric cyclists to obey, although there are no legal sanctions when those provisions are not implemented. As for some of the provisions that are mandatory for electric cyclists that must be obeyed and have legal consequences in the form of legal sanctions if not obeyed, are:

1. In Article 122 of Law 22/2009, it is prohibited that:

a) deliberately allowing the vehicle to be pulled by a motorized vehicle at 
a speed that could jeopardize the safety

b) transporting or pulling objects that can obstruct or endanger other road users

c) use motorized road lanes if a special lane has been provided for non-motorized vehicles.

In Article 100 of Law 22/2009, it is regulated that if these three things are not obeyed, sanctions can be imposed with imprisonment for a maximum of 15 (fifteen) days or a maximum fine of Rp 100,000,00 (one hundred thousand rupiahs). This means that if an electric bicycle rider does not comply with the matters regulated in Article 122 of Law $22 / 2009$, then sanctions can be imposed under those regulated in Article 100 of Law 22/2009

2. In Article 34 paragraph (3) of Government Regulation Number 34 Year 2006 Regarding Roads, it is regulated that the sidewalk as intended only for pedestrian traffic. This means electric bicycles are not allowed to use sidewalks. When electric bicycle riders use the sidewalk, then some sanctions are regulated in the origin of 275 paragraph (1) of Law 22/2009, which is a maximum of 1-month imprisonment or a maximum fine of Rp. 250,000.

After understanding the obligations for electric bicycle riders with sanctions and ones that are only mere recommendations, there are rights for electric bicycle riders. There are special rights for electric bicycle riders, where for example this can be seen in Article 62 paragraph (1) of Law 22/2009, it is stipulated that ease of traffic for cyclists, this, of course, includes for electric bicycle riders. Article 62 paragraph (2) of Law $22 / 2009$ on supporting facilities for security, safety, order and convenience in traffic. In the Elucidation of Article 62 paragraph (2) of Law 22/2009, it is stated that what is meant by "supporting facilities" includes, in the form of special lanes for bicycles, special crossing facilities and / or in conjunction with pedestrians

\section{CONCLUSION}

In its grammatical interpretation, it can be seen in the legislation, that electric bikes which are hybrid vehicles that combine human energy and electrical energy cannot be classified as motorized vehicles, batterybased or non-motorized vehicles. This can also be seen from the interpretation of originalism, wherein the academic text of Law 22/2009 there is no discussion related to hybrid vehicles, let alone electric bicycles, so it can be said that at that time the legislators did not think that there would be electric bicycle which incidentally is a hybrid vehicle that combines electrical and human energy.

To prevent the legal vacuum associated with the regulation of electric bicycles, 
regarding the electric bicycles. law enforcers should interpret the existence of electric bikes progressively, where electric bicycles can be classified as non-motorized vehicles. This is based on the argument that the main source of electric bicycle driving force is human power and an extensive interpretation of electric bikes is an extension of bicycles in general.

The legal consequences that arise when electric bicycles are classified as nonmotorized vehicles, means that there are legal rights and obligations for the electric cyclist. There are two classifications of obligations for electric bicycle riders, where there are obligations that are only suggested/as a recommendation because they do not have sanctions when not implemented and obligations that have sanctions when not implemented. The rights of electric bicycle drivers are special public facilities for electric bicycle riders.

\section{SUGGESTION}

The classification of electric bicycles into non-motorized vehicles is only temporary. This means the classification, is only a temporary solution, not permanent related to the legal standing of electric bicycles. There needs to be a special regulation for electric bikes which incidentally is a hybrid vehicle that combines electric and human energy, which cannot be continuously equated with bicycles and classified as nonmotorized vehicles. Thus, in the future revision of Law 22/2009, there should be an arrangement related to hybrid vehicles which is a vehicle that combines two or more energy sources.

\section{REFERENCES}

Buchanan, Rachel. "The Role Of Technology In The Future Of Legal Professions." University of Oxford, 2017. Https://Www.Law.Ox.Ac.Uk/Res earch-And-Subject-

Groups/Research-Collection-LawAnd-

Technology/Blog/2017/02/RoleTechnology.

Depri Liber Sonata. "Metode Penelitian Hukum Normatif Dan Empiris: Karakteristik Khas Dari Metode Meneliti Hukum." Fiat Justitia Jurnal Ilmu Hukum 8, No. 1 (2017): 25.

Hiariej, Eddy Omar Sharif. "United Nations Convention Against Corruption Dalam Sistem Hukum Indonesia." Mimbar Hukum Fakultas Hukum Universitas Gadjah Mada 31, No. 1 (2019): 112. Doi:10.22146/Jmh.43968.

Hutchinson, Terry. Researching And Writing In Law. Sydney: Lawbook Co, 2002.

Javier, Antonio García, Monsalve Serrano, Rafael Sari, Nikolaos Dimitrakopoulos, Martin Tunér, And Per Tunestål. "Performance And Emissions Of A Series Hybrid Vehicle Powered By A Gasoline Partially Premixed Combustion Engine." Applied Thermal Engineering 150, No. 5 (2019): 564-75.

Marzuki, Peter Mahmud. Penelitian Hukum. Jakarta: Prenada Media Group, 2010.

Mawar, Sitti. "Metode Penemuan Hukum (Interpretasi Dan Konstruksi) Dalam Rangka Harmonisasi 
Hukum." Jurnal Justitia 1, No. 1 (2016): 1-18.

Mohajan, Haradhan. "The First Industrial Revolution: Creation of A New Global Human Era." Journal Of Social Sciences And Humanities 5, No. 4 (2019): 377-87.

Muwahid. "Metode Penemuan Hukum (Rechtsvinding) Oleh Hakim Dalam Upaya Mewujudkan Hukum Yang Responsif." Al-Hukama 7, No. 1 (2017): 225-48.

Nugraha, Xavier, And Ave Maria Frisa Katherina. "Tanggung Jawab Promotor Perseroan Terbatas Terhadap Kontrak Pra Inkorporasi Di Indonesia." Media Iuris 2, No. 127-155 (2019).

Pasaribu, Muksana. "Kedudukan Hukum Islam Dalam Sistem Civil Law Dan Sistem Common Law." Jurnal Justitia 7, No. 1 (2020).

Priono, Agus, Widodo T. Novianto, And I Gusti Ayu Ketut Rachmi Handayani. "Penerapan Teori Penafsiran Hukum Oleh Hakim Sebagai Upaya Perlindungan Hukum Terhadap Notaris (Studi Atas Putusan Hakim Terhadap Tindak Pidana Pemalsuan Akta Otentik)." Jurnal Pasca Sarjana Hukum Uns 5, No. 2 (2017): 11730.

Rachel Berney. Bicycle Urbanism: Reimagining Bicycle Friendly Cities. New York: Routledge, 2018.

Rhiti, Hyronimus. "Landasan Filosofi Hukum Progresif." Justitia Et Pax 32, No. 1 (2016): 34-48.

Sryani Br. Ginting. "Interpretasi Gramatikal Sistematis Historis Kasus Dugaan Penodaan Agama Oleh Ahok." Law Pro Justitia 2, No. 2 (2017): 61-75.

Suanro. "Kewenangan Komisi Yudisial Dalam Tafsir Mahkamah Konstitusi:Kajian Putusan Mahkamah Konstitusi Nomor 43/Puu-Xiii/2015." Jurnal Yudisial 9, No. 2 (2016): 131-50.
Sujana, Bingah Amarwata. "Kedudukan Sepeda Listrik Dalam Hukum Positif Di Indonesia." Hukumonline, 2020.

Https://Www.Hukumonline.Com /Berita/Baca/Lt5e71b6f6af9dc/K edudukan-Sepeda-Listrik-DalamHukum-Positif-Di-IndonesiaOleh--Bingah-Amarwata-Sujana/. Supriyanto, Eko. "Kedudukan Naskah Akademik Dalam Penafsiran Ketentuan-Ketentuan Dalam Undang-Undang." Yuridika 31, No. 3 (2016): 384-400.

Thomas A.J. Mcginn. "The Expressive Function Of Law And The Lex Imperfecta." Roman Legal Tradition 11, No. 1 (2015): 1-41.

Wagiman. "Nilai, Asas, Norma, Dan Fakta Hukum: Upaya Menjelaskan Dan Menjernihkan Pemahamannya." Filsafat Hukum 1, No. 1 (2016): 4373.

А.М., Зезюля. "Вклад В Имущество И ВклаА В Уставный Капитал: Соотношение Понятий." In Российскал Наука В Современном Мире» Xххіiі Межуднародная Научно-Практическал Конференчия, 212-13. Moscow: Research And Publishing Center, 2020. 